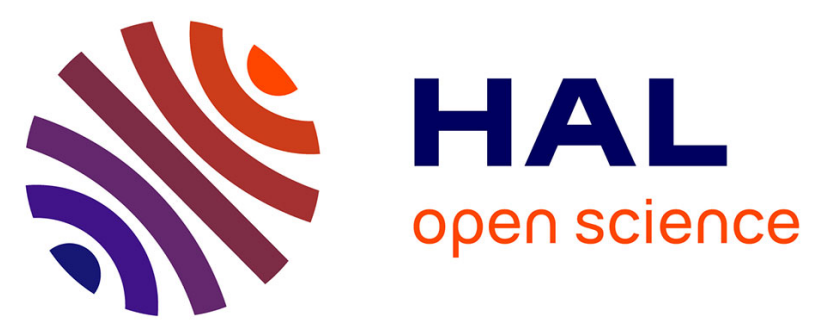

\title{
A water-soluble and incubate-free fluorescent environment-sensitive probe for ultrafast visualization of protein thiols within living cells
}

Xiaolu Li, Qian Feng, Lejing Qu, Ting Zhao, Xiaoan Li, Tiantian Bai, Shisheng Sun, Shaoping Wu, Yongmin Zhang, Jianli Li

\section{To cite this version:}

Xiaolu Li, Qian Feng, Lejing Qu, Ting Zhao, Xiaoan Li, et al.. A water-soluble and incubate-free fluorescent environment-sensitive probe for ultrafast visualization of protein thiols within living cells. Analytica Chimica Acta, 2020, 1126, pp.72-81. 10.1016/j.aca.2020.06.026 . hal-02898203

\section{HAL Id: hal-02898203 \\ https: / hal.sorbonne-universite.fr/hal-02898203}

Submitted on 13 Jul 2020

HAL is a multi-disciplinary open access archive for the deposit and dissemination of scientific research documents, whether they are published or not. The documents may come from teaching and research institutions in France or abroad, or from public or private research centers.
L'archive ouverte pluridisciplinaire HAL, est destinée au dépôt et à la diffusion de documents scientifiques de niveau recherche, publiés ou non, émanant des établissements d'enseignement et de recherche français ou étrangers, des laboratoires publics ou privés. 


\section{A water-soluble and incubate-free fluorescent environment-sensitive}

probe for ultrafast visualization of protein thiols within living cells

Xiaolu Li ${ }^{\mathrm{a}, \mathrm{b}}$, Qian Feng ${ }^{\mathrm{a}, \mathrm{b}}$, Lejing Qu ${ }^{\mathrm{a}, \mathrm{b}}$, Ting Zhao ${ }^{\mathrm{a}}$, Xiaoan $\mathrm{Li}^{\mathrm{a}, \mathrm{b}}$, Tiantian Bai ${ }^{\mathrm{a}, \mathrm{b}}$, Shisheng Sun ${ }^{\mathrm{a}}$, Shaoping Wu $\mathrm{u}^{\mathrm{a}, \mathrm{b}, *}$, Yongmin Zhang ${ }^{\mathrm{a}, \mathrm{b}, \mathrm{c}}$, Jianli $\mathrm{Li}^{\mathrm{d}}$

${ }^{a}$ Key Laboratory of Resource Biology and Biotechnology in Western China (Northwest University), Ministry of Education; Biomedicine Key Laboratory of Shaanxi Province, Northwest University, Xi'an 710069, P. R. China

b Joint International Laboratory of Glycobiology and Medicinal Chemistry, Northwest University, Xi'an, Shaanxi 710069, P. R. China

c Sorbonne Université, CNRS, Institut Parisien de Chimie Moléculaire, UMR 8232, 4 place Jussieu, 75005 Paris, France

${ }^{\mathrm{d}}$ Key Laboratory of Synthetic and Natural Functional Molecule Chemistry of Ministry of Education, College of Chemistry \& Materials Science, Northwest University, Xi'an, Shaanxi 710127, P. R. China

* Tel.: +86 029 88304569; Fax: +86 029 88304569. E-mail: wushaoping@ @wu.edu.cn

\section{Abstract:}

The amount of protein thiols play a crucial role in maintaining the cellular redox homeostasis and have significant implications to indicate a series of diseases. Therefore, it is necessary to develop an ideal probe for protein thiol detection in a simple and readily implementable method. Consequently, a water-soluble and incubate-free fluorescent environment-sensitive probe DMTs-OCC was synthesized using 7-diethylamincoumarin as the fluorophore and 4-(5-Methanesulfonyl-[1,2,3,4]tetrazol-1-yl)-phenol (MSTP) as a thiol receptor reagent. The blue-shift emission spectra of probe DMTs-OCC was observed by ultrafast binding to protein sulfhydryl groups from the excited intramolecular charge transfer (ICT) to the twisted intramolecular charge transfer (TICT) conversion process in aqueous solution. The experimental results showed that probe DMTs-OCC exhibited an excellent selectivity to protein thiols and biocompatibility in aqueous solution, as well as terrific cell membrane permeability which enabled the successful visualization of BSA protein thiol in living cells. Moreover, no excess probe was cleaned and no incubation time was needed in cell experiments. Therefore, it could provide a new method to the construction of fluorescent probes for protein thiols 
labelling and visualization.

Keywords: Environment-sensitive, Fluorescent probe, Protein thiols, Coumarin, BSA, Bioimaging

\section{Introduction}

Proteins, consisting of one or more peptide chains and folding into a globular or fibrous form, mediate virtually every process that takes place in a cell, exhibiting an almost endless diversity of functions thereby attracting much attention of researchers all the time. Many studies have been carried out to elucidate the structures, dynamics and interactions of proteins. [1]. Among multiple proteins, protein cysteine residues play a very important role in the majority of physiological and biological processes, such as maintaining cell redox homeostasis, cell proliferation and apoptosis [2] and signal transduction, which is targets of numerous posttranslational modifications [3]. Similarly to phosphorylation, the reversible oxidation of protein cysteine residues has an administrative role to play in protein function, protein folding and intracellular trafficking [4]. Normally, there are two major groups of thiols in biological systems including low molecular weight thiols and protein thiols, while protein cysteine residues are the main source of protein thiols. The level of the amount of protein thiols has the capacity to indicate many diseases such as chronic obstructive pulmonary disease [5], Alzheimer's disease [6], Parkinson's disease [7] and diabetes mellitus [8].

In thiol proteome, the mixed disulfides (RS-SR', SR' low molecular weight thiols), nitrosothiols (RS-NO), sulfenic acids ( $\mathrm{RSOH})$, sulfonic acids $\left(\mathrm{SO}_{3} \mathrm{H}\right)$, sulfinic acids $\left(\mathrm{SO}_{2} \mathrm{H}\right)$, S-lipidation (palmitoylation, RS-COR), and perthiols (RS-SH) are a range of functional groups owning distinctive chemical characteristics which is reversible [9]. These diverse chemical and kinetic properties make it difficult to select and determine proteins thiols at cysteine sites in situ, analysis and bioimaging of protein thiols has thus become a highly challenging task for biologists and chemists.

Some conventional methods were used in the determination of thiols including high performance liquid chromatography $[10,11]$ and capillary electrophoresis $[12,13]$. 
Particularly, many biophysical techniques for analysis and bioimaging of protein thiols were provided through modifying protein thiols with a functional group, such as fluorophore, a mass marker, or a magnetic group [14].As one of the most powerful weapons in the area of biosensing and bioimaging, fluorescent probe can detect protein directly in situ and provide more information at the biomolecular level. Among various fluorescent probes, fluorescent environment-sensitive probes can be regarded as a specific pigmentation due to the fact that their fluorescence intensity and colors have the ability to change with the micro-environmental polarity and viscosity [15]. Therefore, fluorescence environment-sensitive probes for analysis and imaging has been constructed as one of the most important techniques for investigating protein thiols because of its excellent properties including sensitivity, selectivity, simple sample treatment and technical practicality [16].

At present, various chemical methods of thiol group detection in proteins have been developed and the basic principle of those methods is to use specific small molecules to react with thiol group, whereas other groups of a protein, such as amino group and carboxyl group, would not react under the same condition. In this way, the purpose of specific detection of thiol group in proteins can be achieved. In 1983, the first small-molecular probe SBD-F was developed for the detection of thiol on protein by Toyo'oka group [17], which can selectively react with thiol group under alkaline conditions via $S_{N} 2$ substitution reaction. In recent years, some probes of thiol group detection have been quickly developed by adding various fluorophore based on Michael addition reaction type utilizing thiol addition to the N-ethylmaleimide (NEM) moiety [18] and $\alpha, \beta$-unsaturated ketones [19] (Fig. 1a). However, some chemical and biological problems of those methods, including stringent reaction conditions, low reaction rate constant, poor water solubility and etc., could not be ignored. Therefore, it is necessary to tackle those problems mentioned above so as to develop an ideal thiol detection probe on protein with simple methods.

Our group has recently focused on the design and synthesis of novel fluorescent probes [20]. In this work, we would like to report a highly fluorescent environment-sensitive probe for the ultrafast reaction, water-soluble and incubate-free 
visualization of detection and label thiol group on protein. We designed and synthesized an environment-sensitive probes using 7-diethylamincoumarin as fluorophore [21] (Fig. 1b). MSTP was used as a thiol receptor reagent in procedures to identify the protein persulfides [22]. In aqueous water media, a weak fluorescence emission was only observed due to existing twisted intramolecular charge transfer (TICT) the excited states upon photoexcitation. On the contrary, the fluorescence intensity of probe 7-(diethylamino)-N-(3-(4-(5-(methylsulfonyl)-1-Htetrazol-1-yl)phenoxy)propyl)-2-oxo-2H-chromene-3-carboxamid (DMTs-OCC) sharply increased by about 11-fold when adding the protein After the protein thiols selectively bound to the MSTP group of probe DMTs-OCC, the operating environment of probe DMTs-OCC altered from a polar aqueous medium to a hydrophobic protein microenvironment. As a result, TICT process was restricted under the environment of a lower polarity around probe DMTs-OCC. Besides, a blue-shift intramolecular charge transfer (ICT) emission band obviously appeared at $465 \mathrm{~nm}$ in the fluorescence spectra. The experimental results also demonstrated that probe DMTs-OCC could detect protein thiols with ultrafast selectivity by analyzing biological samples in aqueous solutions. Additionally, without incubation time, probe DMTs-OCC has successfully achieved thiol binding to bovine serum protein (BSA) in living cells and there was no excess probes being clean.

(a) Previous work

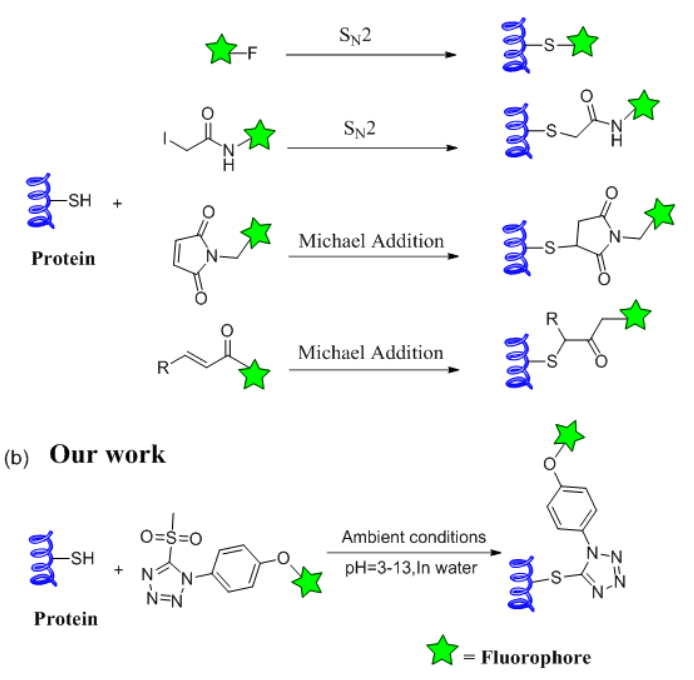

Fig.1. Fluorescence probes of thiol group detection. 


\section{Materials and methods}

\subsection{General procedure and Materials for sample preparation}

All reagents with analytical grades were obtained from $J \& K$ Scientific Ltd. (Shanghai China). All reactions were magnetically stirred in dry glassware. Probe DMTs-OCC and reference compound Ctrl were dissolved in dimethyl sulfoxide (DMSO) as storing solution. Preparation and preservation of BSA and other amino acids were based on the literature [ 23 ]. Hitachi F-7000 fluorescence spectrophotometer was used to record the fluorescence spectra. The related spectra of synthesized compounds were displayed in the Supplementary Information.

\subsection{Synthesis of probe DMTs-OCC}

To a solution of $\mathbf{S 3}$ (14 mg, $0.054 \mathrm{mmol}, 1.0$ eq.), N,N'-disuccinimidyl carbonate (DSC) (21 mg, $0.081 \mathrm{mmol}, 1.5$ eq.) and 4-dimethylaminopyridine (DMAP) (8 mg, $0.065 \mathrm{mmol}, 1.2$ eq.) in DMF ( $5 \mathrm{~mL}$ ), and the mixture was stirred for $1 \mathrm{~h}$, then added $\mathbf{R}-\mathbf{N H}_{2}$ (48 $\mathrm{mg}, 0.16 \mathrm{mmol}, 3.0$ eq.), the mixture was reacted at room temperature for $4 \mathrm{~h}$. Then the mixture was added to saturated $\mathrm{NaCl}$ solution which was filtered and dried to afford a yellow precipitate, the crude material was purified by flash column chromatography $(\mathrm{PE}: \mathrm{EtOAc}=2: 1)$ yielding the probe DMTs-OCC $(20 \mathrm{mg}, 68.5 \%$ yield $)\left(\mathrm{PE}: \mathrm{EtOAc}=1: 3, \mathrm{R}_{\mathrm{f}}=0.45\right) .{ }^{1} \mathrm{H} \mathrm{NMR}\left(400 \mathrm{MHz}, \mathrm{CDCl}_{3}\right) \delta 9.07(\mathrm{~s}, 1 \mathrm{H}, \mathrm{H}-\mathrm{h})$, 8.71 (s, 1H, H-i), 7.58 (s, 2H, H-n, H-o), 7.43 (s, 1H, H-g), 7.15 (s, 2H, H-m, H-p),

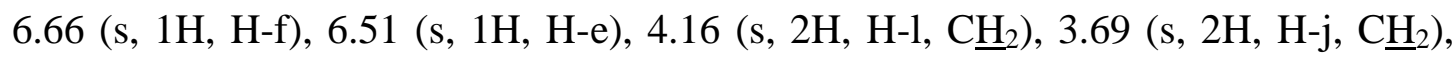
3.61 (s, 3H, H-q, $\underline{\mathrm{H}}_{3}$ ), 3.46 (d, J = $\left.7.1 \mathrm{~Hz}, 4 \mathrm{H}, \mathrm{H}-\mathrm{c}, \mathrm{H}-\mathrm{d}, \mathrm{C}_{2}\right), 2.17$ (s, 1H, H-k), 2.09-1.98 (m, 1H, H-k), 1.28 (s, 3H, H-a, $\underline{\mathrm{CH}}_{3}$ ), 1.22 (s, 3H, H-b, $\left.\underline{\mathrm{H}}_{3}\right) .{ }^{13} \mathrm{C} \mathrm{NMR}$ $\left(101 \mathrm{MHz}, \mathrm{CDCl}_{3}\right) \delta 163.36,162.80,161.09,157.66,148.18,131.18,129.50,126.36$, $125.52,115.39,110.14,109.97,108.37,100.00,96.56,66.82,45.11,43.80,37.13$, 29.73, 29.13, 12.43. HRMS $\left(\mathrm{C}_{25} \mathrm{H}_{28} \mathrm{~N}_{6} \mathrm{O}_{6} \mathrm{~S}\right)$ : calcd. for $[\mathrm{M}+\mathrm{H}]^{+}$563.1689; found: $[\mathrm{M}+\mathrm{H}]^{+}$563.1663. (Fig. S8, S16-S17)

\subsection{Titration experiments of probe DMTs-OCC}

In the fluorescence titration experiments, a solution of probe DMTs-OCC was prepared using DMSO solution to provide a stock solution with a concentration of 1 
$\mathrm{mM}$, and the BSA was dissolved in deionized water to prepare a BSA solution. The stock solution was then formulated into different concentrations for further use. Typically, $2.0 \mu \mathrm{L}$ of DMTs-OCC reserve solution was absorbed and diluted to $5 \mathrm{~mL}$ with phosphate buffer solution $(10 \mathrm{mM}, \mathrm{pH}=7.4)$. Fluorescence intensity was measured in a $10 \mathrm{~mm}$ quartz cuvette $\left(\lambda_{\mathrm{ex}}=425 \mathrm{~nm}\right)$ and scanned at a rate of $1200 \mathrm{~nm}$ $\min ^{-1}$.

\subsection{Cell culture and fluorescence imaging}

To detect the living cell fraction, the cytotoxicity of probe DMTs-OCC was quantified through CCK-8 assay. Cells were incubated at $37{ }^{\circ} \mathrm{C}$ under $5 \% \mathrm{CO}_{2}$ and treated for $24 \mathrm{~h}$ in $10 \%$ fetal bovine serum (FBS) containing dulbecco's modification of eagle's medium (DMEM) supplemented. After the cells were incubated with probe DMTs-OCC containing different concentrations $(0,2,4,6,8,10,15$ and $20 \mu \mathrm{M})$ of test compounds and controls for $24 \mathrm{~h}$ in the same conditions, the absorbance was recorded at $450 \mathrm{~nm}$ using a microplate reader when CCK-8 $(10 \mu \mathrm{L})$ was added to each hole for $3 \mathrm{~h}$ at $37{ }^{\circ} \mathrm{C}$. The experiment was repeated five times carefully for each treatment group.

For intracellular imaging of protein thiols, SH-SY5Y cells (purchased from the ATCC Cell Bank) were deposed on a $20 \mathrm{~nm}$ glass coverslips and glued for $24 \mathrm{~h}$, the cells were incubated with $5 \mu \mathrm{M}$ of probe DMTs-OCC for $15 \mathrm{~min}$ at $37{ }^{\circ} \mathrm{C}$ before confocal scanning imaging. After incubation, imaging was captured using confocal laser scanning microscope FV1000 without wash. It was excited at the wavelength of $425 \mathrm{~nm}$ and collected the emission light within the range from 450 to $550 \mathrm{~nm}$.

\section{Results and discussion}

\subsection{Design and synthesis of probe DMTs-OCC}

In our study, 7-diethylaminocoumarin as an environment-sensitive fluorophore, was linked to the MSTP to form probe DMTs-OCC for fluorescence turn-on labeling of BSA protein. It is clear that the 7-dialkylaminocoumarin was a solvent-chromic dye that exhibits dim fluorescence in polar solvents and bright fluorescence in low-polar solvents [24]. On the other hand, owing to good selectivity and reaction with -SH 
blocker, MSTP can be used as the selectivity recognition group which was compatible in the analysis of biological samples. Similarly to N-ethylmaleimide (NEM), MSTP can also permeate through the cell membrane to quench thiols of intracellular cells in a short time.

The synthetic procedure and route for probe DMTs-OCC as well as reference compound Ctrl were shown in Scheme 1 and Scheme S1 respectively. Starting material 1-(4-Hydroxyphenyl)-5-mercapto-1H-tetrazol reacted with iodomethane in the presence of a small amount of triethylamine to quantitatively give 4-(5-(methylthio)-1H-tetrazol-1-yl)phenol (R1) in anhydrous THF. Then compound R1 was heated with tert-butyl (3-chloropropyl) carbamate in DMF using a catalytic amount of $\mathrm{Cs}_{2} \mathrm{CO}_{3}$, followed by oxidation with $30 \% \mathrm{H}_{2} \mathrm{O}_{2}$ to obtain compound $\mathbf{R 3}$. Finally, 7-(diethylamino)-2-oxo-2H-chromene-3-carboxylic acid reacted with compound $\mathbf{R 3}$ in the presence of DSC and DMAP to produce probe DMTs-OCC.

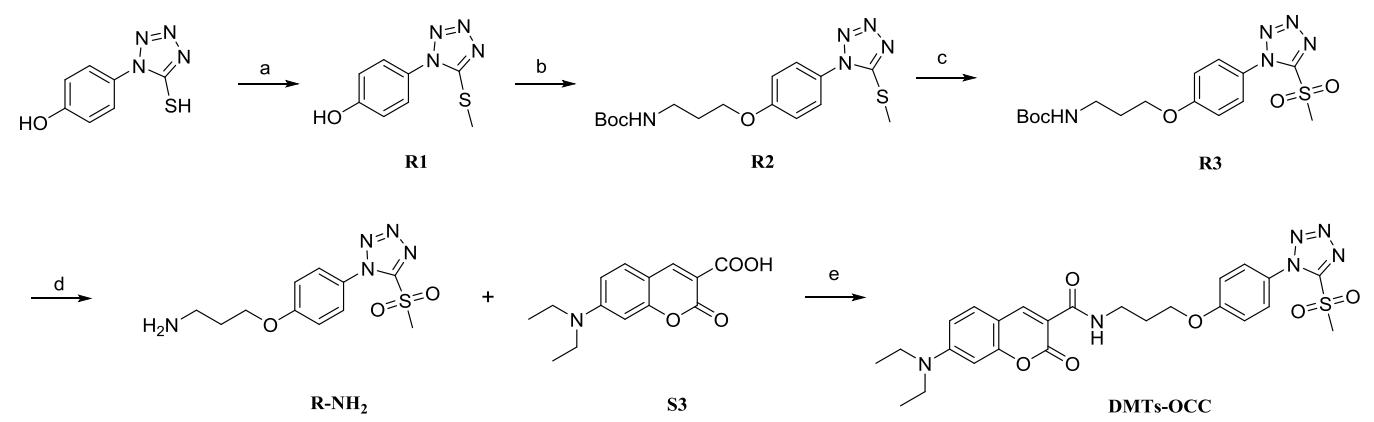

Reagents and conditions: (a) Iodomethane, Triethylamine, THF, overnight, rt., quantitative; (b) S1, $\mathrm{Cs}_{2} \mathrm{CO}_{3}$, DMF, $80^{\circ} \mathrm{C}$ overnight, $64.4 \%$; (c) $\mathrm{Na}_{2} \mathrm{WO}_{4} \cdot \mathrm{H}_{2} \mathrm{O}, 30 \% \mathrm{H}_{2} \mathrm{O}_{2}$, EtOH, overnight, rt., 70.2\%; (d) Concentrated hydrochloric acid, EtOAc, rt., 3 h, without further purification. (e) DSC, DMAP, DMF, rt. 5 h. $68.5 \%$.

Scheme 1. Synthesis of probe DMTs-OCC.

\subsection{Environment-sensitive studies of probe DMTs-OCC}

The fluorescence characteristics of probe DMTs-OCC were investigated by carefully measuring its emission spectra $\left(\lambda_{\mathrm{ex}}=425 \mathrm{~nm}\right)$ in the mixture of 1,4-dioxane and water of unequal polarities. As the ratio of 1,4-dioxane in the mixture 1,4-dioxane-water solution grew from $0 \%$ to $99 \%$ (Fig. 2a), concomitant showed a 61-fold increase. The fluorescence intensity was attributed to the TICT process, which was similar to conventional solvatochromic dyes and usually shows strong fluorescence intensity in polar environment. Then the intensity of probe DMTs-OCC 
was tested in ethanol and water of different polarities. The ethanol fraction $\left(f_{d}\right.$, by volume \%) in the $\mathrm{MeOH} /$ glycerol solution rised from $0 \%$ to $99 \%$, and the TICT was emitted, and at the same time the intensity also gradually increased (Fig. 2b).
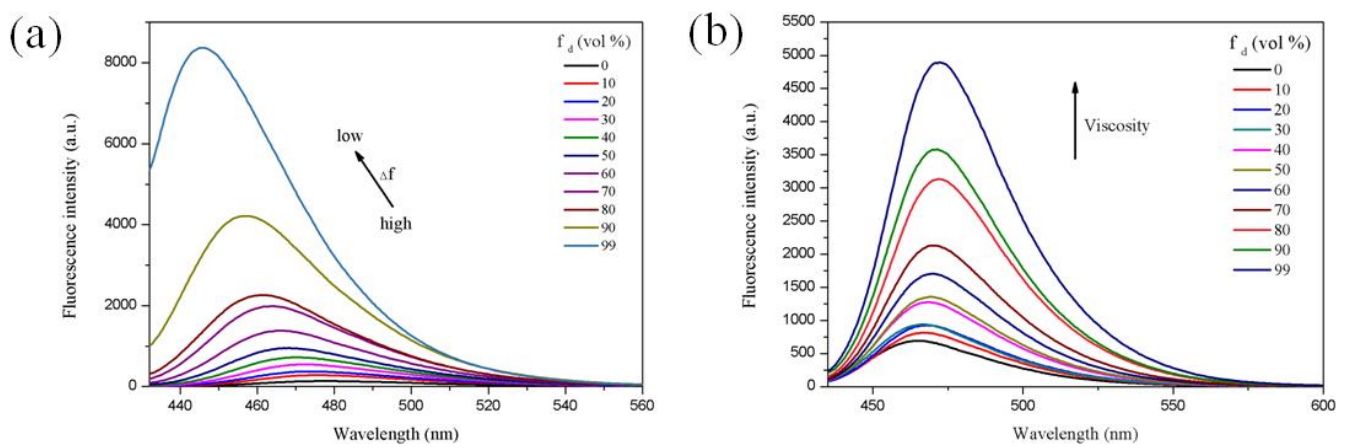

Fig.2. Fluorescence spectra $\left(\lambda_{\mathrm{ex}}=425 \mathrm{~nm}, \lambda_{\mathrm{em}}=465 \mathrm{~nm}\right)$ of DMTs-OCC $(0.4 \mu \mathrm{M})$ in (a) water / 1,4-dioxane mixtures and (b) $\mathrm{MeOH} /$ Glycerol mixtures. Slits: $2.5 \mathrm{~nm} / 5.0 \mathrm{~nm}$, volt: $700 \mathrm{~V}$.

\subsection{Fluorescent responses of probe DMTs-OCC to protein thiols}

Quantification of DMTs-OCC probes by fluorescence titration was carried out and BSA was used as a model protein. In the fluorescence emission study, little fluorescence was perceived in $480 \mathrm{~nm}$ of probe DMTs-OCC when it was excited at $425 \mathrm{~nm}$. After the reaction with BSA, a split-new emission peak could be easily observed at $465 \mathrm{~nm}$. Even if a low level of BSA could also increase the fluorescence intensity of probe DMTs-OCC by about 11-fold (Fig. S1). These results indicated that probe DMTs-OCC was a sensitive probe to detect BSA. Meanwhile, the emission spectrum of probe DMTs-OCC $(0.4 \mu \mathrm{M})$ with the addition of BSA was shown in Fig. 3. Probe DMTs-OCC showed weak fluorescence intensity at $480 \mathrm{~nm}$ at the excitation wavelength of $425 \mathrm{~nm}$, but the emission intensity increased significantly at $465 \mathrm{~nm}$.

Probe DMTs-OCC showed a weak fluorescence at $480 \mathrm{~nm}$ at the excitation wavelength of $425 \mathrm{~nm}$, when different concentrations of BSA were added to the probe solution, the emission intensity increased significantly at $465 \mathrm{~nm}$, and there was an excellent linear relationship between the BSA concentration (from 0.5 to $6.0 \mu \mathrm{M}$ ) and fluorescence intensity $\left(\mathrm{R}^{2}=0.9972\right)$, No co-solvents were added during the experiment. The results indicated that the probe was a water-soluble probe for detecting protein 
thiols and can effectively avoid the effects of organic solvents on protein properties.
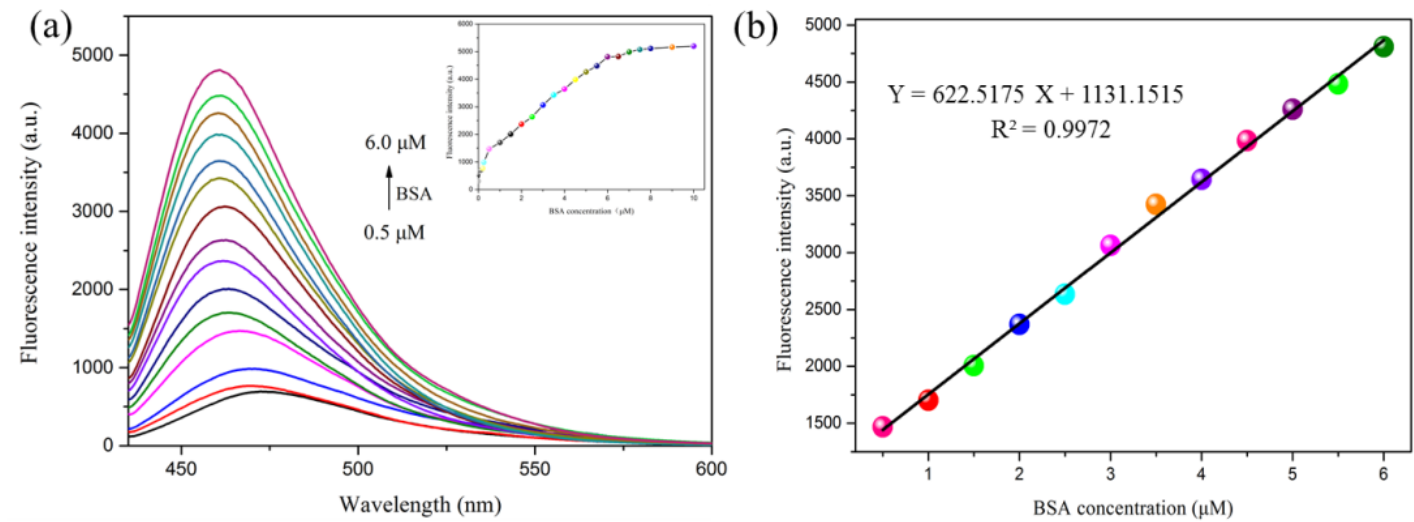

Fig.3. (a) Fluorescence intensity of DMTs-OCC $(0.4 \mu \mathrm{M})$ in the case of BSA $(0.5 \sim 6.0 \mu \mathrm{M})$ in phosphate buffer $(10 \mathrm{mM}, \mathrm{pH} 7.4)$ at room temperature; (b) Linearity of fluorescence intensity at $465 \mathrm{~nm}$ with concentrations of BSA. $\lambda_{\mathrm{ex}}=425 \mathrm{~nm}$, slits: $5.0 \mathrm{~nm} / 5.0 \mathrm{~nm}$, volt: $700 \mathrm{~V}$. Inset: (a) intensity of DMTs-OCC in the presence of BSA $(0.0 \sim 10.0 \mu \mathrm{M})$.

According to the $3 \sigma / \mathrm{k}$ protocol described in Table S2, the detection limit of BSA was calculated to be $9.8 \mathrm{nM}\left(\mathrm{R}^{2}=0.9972\right)$. This datum proved that probe DMTs-OCC could be successfully used for quantitative determination of BSA in phosphate buffer rapidly with a higher sensitivity, better selectivity, and lower detection limit than the probes reported in literatures in Table S1. Moreover, no incubation time was required in living cell experiments.

\subsection{Working pH range and time- response to protein thiols}

In order to be suitable for biological fluorescent imaging in cells, probe DMTs-OCC must operate well within the appropriate physiological $\mathrm{pH}$ ranges. Therefore, the sensitivity of probe DMTs-OCC to BSA was tested at various $\mathrm{pH}$ values (3-13) using fluorescence spectrometry (Fig. 4a). The changes in probe DMTs-OCC fluorescence over time toward protein thiols were also studied. As shown in Fig. $\mathbf{4 b}$, the fluorescence intensity of probe DMTs-OCC responded quickly (<1s) at $465 \mathrm{~nm}$ and almost remained the same after the reaction, which indicated that probe DMTs-OCC could act as a "rapid response" sensor for BSA detection and monitor protein thiols standard for real time in living cells (physiological condition $\mathrm{pH}=7.4)$. 

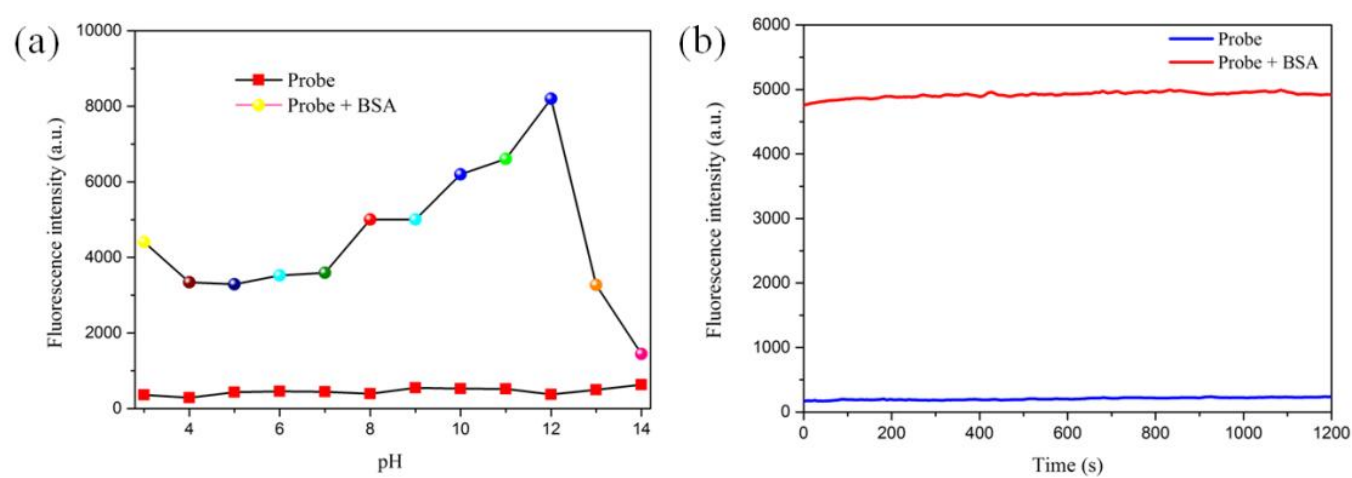

Fig.4. (a) Changes in spectra of DMTs-OCC $(0.4 \mu \mathrm{M})$ as a function of pH. (b) Time-dependent changes of DMTs-OCC $(0.4 \mu \mathrm{M})$ with BSA $(6.0 \mu \mathrm{M})$ in phosphate buffer $(10 \mathrm{mM}, \mathrm{pH} 7.4), \lambda_{\mathrm{ex}}=$ $425 \mathrm{~nm}, \lambda_{\mathrm{em}}=465 \mathrm{~nm}$, slits: $5.0 \mathrm{~nm} / 5.0 \mathrm{~nm}$, volt: $700 \mathrm{~V}$.

\subsection{Selectivity and competition of probe DMTs-OCC to protein thiols}

The Fig. 5a showed the response of probe DMTs-OCC $(0.4 \mu \mathrm{M})$ in the presence of various amino acids and BSA. Only BSA could cause a significant fluorescence enhancement in the probe solution. In order to verify the versatility of the probe, human serum albumin (HSA) was sieved under the same conditions, and the result indicated that HSA had a fluorescence response which was similar to BSA (Fig. S2). Considering that different protein thiols exhibited different reactivity to probe DMTs-OCC, further investigation of the response of probe DMTs-OCC to various low-molecular weight thiols was also carried out (Fig. S3), we found that the probe exhibited a strong fluorescence intensity variation to protein thiols such as BSA and HSA, while GSH, Cys and Hcy elicited only marginal fluorescence signal. Then the anti-interference capacity of probe DMTs-OCC against other analytes was also detected, as shown in the fig. $\mathbf{5 b}$, amino acids and other biological samples did not interfere with the detection of BSA, and only the solution with the addition of BSA showed color changes (Fig. 5d). The results revealed that probe DMTs-OCC had a meritorious BSA selectivity against a variety of potential interfering species in cells, and could detect protein thiols in complex biological systems with a high specificity. 


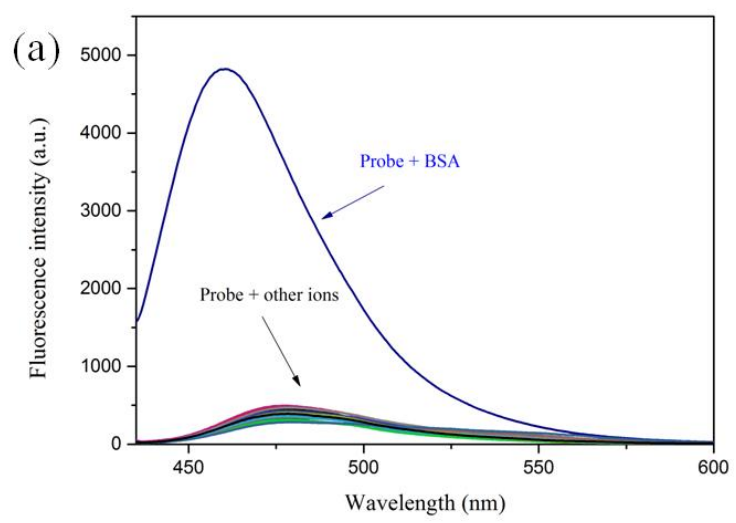

(b)
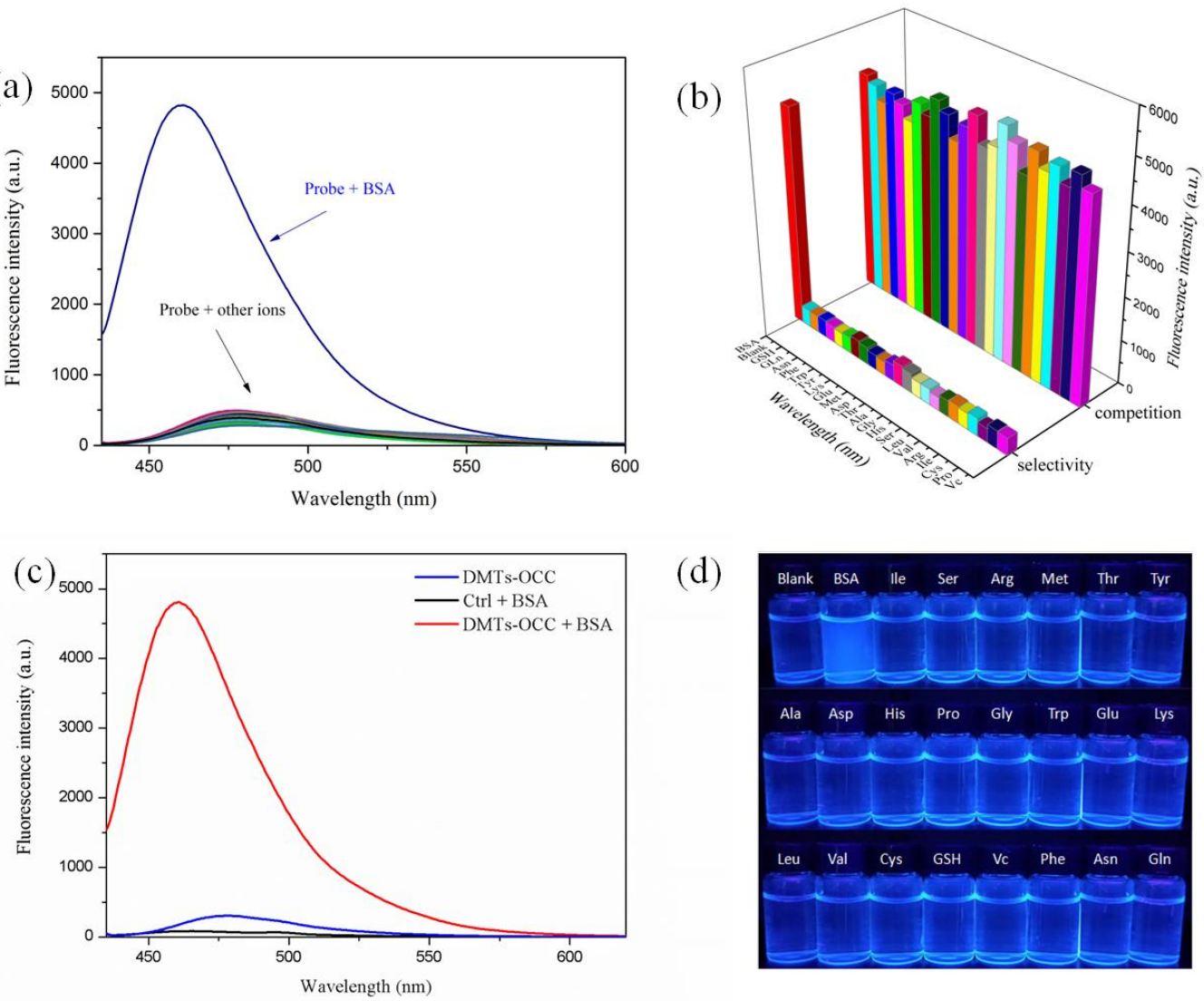

(d)

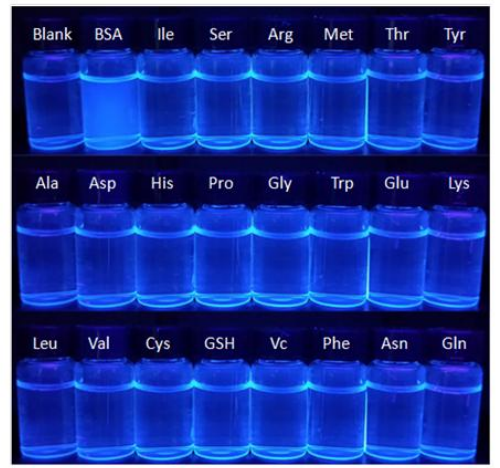

Fig.5. (a) Spectra of DMTs-OCC $(0.4 \mu \mathrm{M})$ with $6.0 \mu \mathrm{M}$ BSA and 22 different other ions $(6.0 \mathrm{mM})$ in phosphate buffer $(10 \mathrm{mM}, \mathrm{pH}$ 7.4). (b) Spectra response of DMTs-OCC $(0.4 \mu \mathrm{M})$ in the presence of various anions $6.0 \mathrm{mM}$ in response to BSA $(6.0 \mu \mathrm{M})$, the detection medium was in phosphate buffer $(10 \mathrm{mM}, \mathrm{pH} 7.4)$. (c) Fluorescence spectra of DMTs-OCC $(0.4 \mu \mathrm{M})$ and control upon addition of $6.0 \mu \mathrm{M}$ BSA in phosphate buffer $(10 \mathrm{mM}, \mathrm{pH} 7.4)$. (d) Color changes of DMTs-OCC $(0.4 \mu \mathrm{M})$ after adding BSA $(6.0 \mu \mathrm{M})$ and other different amino acids $(6.0 \mathrm{mM}) . \lambda_{\mathrm{ex}}=$ $425 \mathrm{~nm}, \lambda_{\mathrm{em}}=465 \mathrm{~nm}$, slits: $5.0 \mathrm{~nm} / 5.0 \mathrm{~nm}$, volt: $700 \mathrm{~V}$.

\subsection{Mechanism of binding to protein thiols}

In this study, the binding mechanism of probe DMTs-OCC to the protein thiols was also investigated by using mass spectrometry [25]. Firstly, BSA was used as the model protein. After the addition of the low-molecular weight thiols, such as Cysteine, Homocysteine and GSH, fluorescence intensity of probe DMTs-OCC showed no significant difference. However, after adding BSA, an intense emission was observed at $465 \mathrm{~nm}$ when excited at $425 \mathrm{~nm}$. In order to further verify that the increase in fluorescence was attributed to the steric hindrance and the hydrophobic environment of the protein, BSA was pretreated with guanidine hydrochloride $(\mathrm{GdnHCl})$ for denaturation and the fluorescence intensity of BSA was significantly reduced in the presence of protein denaturant (Fig. S4). On the whole, these results showed that 
probe DMTs-OCC could monitor protein thiols through the enhancement of fluorescence signal.

The LC-MS/MS results showed that probe DMTs-OCC selectively modified the thiol groups of proteins. As an example showed in Fig. 6, probe DMTs-OCC bound to the free thiol group of Cys86 on BSA, proving that probe DMTs-OCC modified the protein thiol group with high specificity (Fig. S5-S6).

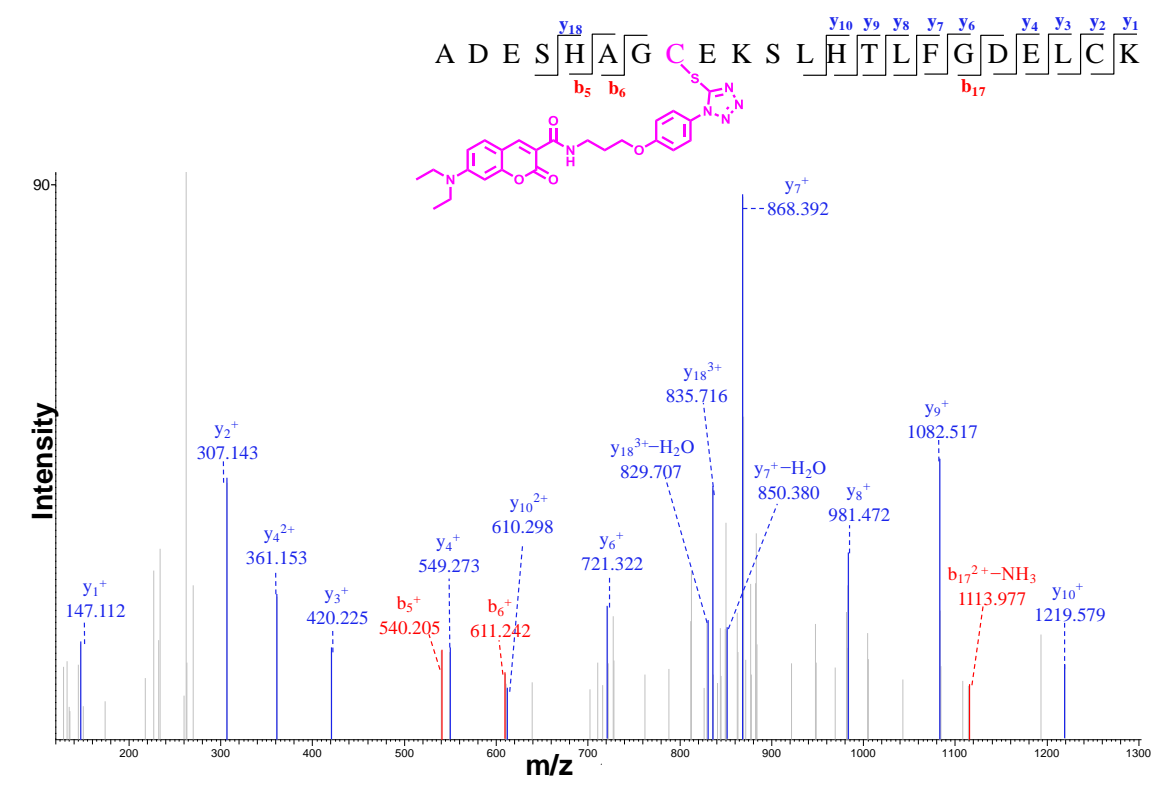

Fig.6. LC-MS/MS analysis of digested DMTs-OCC-labeled BSA. (a) HCD MS/MS spectrum of major DMTs-OCC-modified $(\triangle \mathrm{M}=460.186)$ Cys-tag peptides, Y-axis is zoomed in to show fragment peaks.

\subsection{Fluorescence imaging for the detection of protein thiols in living cells}

CCK-8 assay was used to determine the cytotoxicity of probe DMTs-OCC before the imaging experiments of living cells. When SH-SY5Y cells were incubated with probe DMTs-OCC for 24 hours, the probes with concentration less than $20 \mu \mathrm{M}$ showed no significant cytotoxicity (Fig. S7). Next, the cells were stained with/without probe DMTs-OCC (10 $\mathrm{mM})$ for $30 \mathrm{~min}$ respectively, and the group of cells that added to probe DMTs-OCC did not require repeated cleaning to remove excess probes. The result showed that fluorescence intensity was only observed in the group that adding probe DMTs-OCC (Fig. 7, panel e) and excess probes did not affect the experimental results. SH-SY5Y cells were used to be incubated with the reference compound Ctrl and no fluorescence was observed. (Fig. 7, panel h). However, when the cells were incubated with a thiol alkylating reagent $N$-ethylmaleimide (NEM, 100 
$\mathrm{mM}$ ) for $30 \mathrm{~min}$, then pretreated with probe DMTs-OCC (Fig. 8, panel h), weak fluorescence emerged. These consequences indicated that the probe DMTs-OCC was appropriate for imaging protein thiols in living cells.

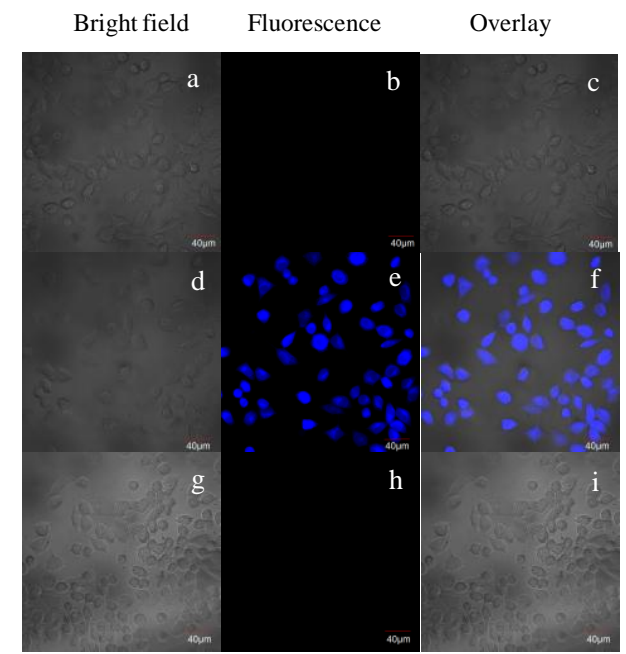

Fig.7. Imaging protein thiols in living cells. (a), (b) and (c) were confocal images of SH-SY5Ycells without DMTs-OCC. (d), (e) and (f) were microscopy images of SH-SY5Y cells incubated with the DMTs-OCC $(5 \mu \mathrm{M})$ for $15 \mathrm{~min}$ at $37^{\circ} \mathrm{C}(\mathrm{g})$, (h) and (i) were confocal images of SH-SY5Y with the reference compound $\mathbf{C t r l}$ for $15 \mathrm{~min}$ at $37^{\circ} \mathrm{C}$.
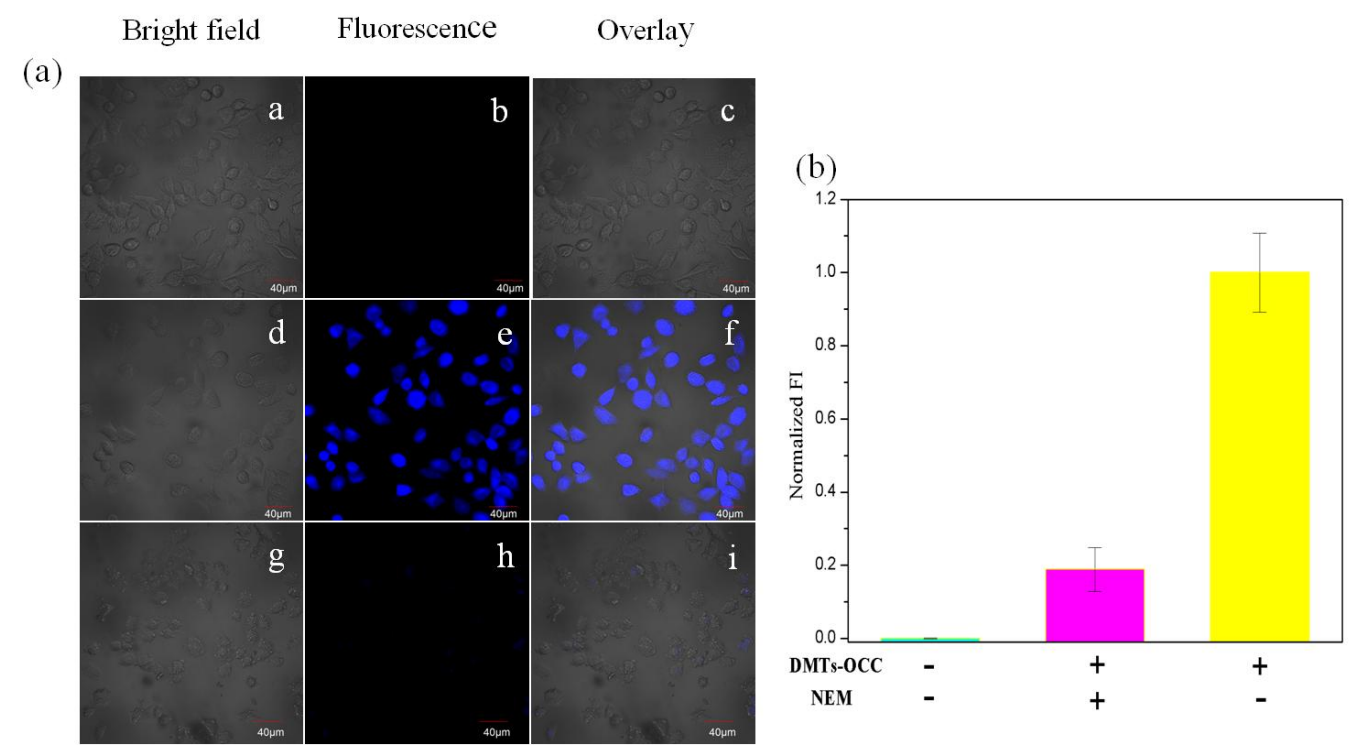

Fig.8. Imaging of protein thiols in living cells. (a), (b) and (c) were confocal images of SH-SY5Y cells. (d), (e) and (f) were confocal images of SH-SY5Y with DMTs-OCC (5 $\mu \mathrm{M})$ for 15 min at $37^{\circ} \mathrm{C}$. (g), (h) and (i) were confocal images of SH-SY5Y with the NEM $(100 \mu \mathrm{M})$ for $30 \mathrm{~min}$ at $37^{\circ} \mathrm{C}$ and further incubated with DMTs-OCC $(5 \mu \mathrm{M})$ for $15 \mathrm{~min}$; quantification is shown on the right $(b)(n=3)$.

\section{Conclusion}

In summary, we have rationally designed and synthesized a fluorescence environment-sensitive probe DMTs-OCC using 7-diethylamincoumarin as 
fluorophore and MSTP as a thiol receptor reagent for the purpose of identifying protein sulfides. The experimental results demonstrated that probe DMTs-OCC, undergoing the ICT-TICT conversion process, could label and detect protein thiols with ultrafast $(<1 \mathrm{~s})$ selectivity through the analysis of biological sample in aqueous solutions under room temperature Furthermore, probe DMTs-OCC with an excellent cell membrane permeability has successfully visualized BSA protein thiols in living cells with no excess probes cleaned and no incubation time required. The new probe DMTs-OCC is prospected to serve as a powerful chemosensor tool for visualization of protein thiols in various biological systems.

\section{Acknowledgements}

This work was supported by the National Natural Science Foundation of China (No. 21572177), the International Science \& Technology Cooperation Program of Shaanxi Province (No. 2019KWZ-001), Biomedicine Key Laboratory of Shaanxi Province Program (No. 2018SZS41), and Program of Innovation for Undergraduates of Northwest University (No. 2019253).

\section{Appendix A. Supplementary data}

Supplementary data associated with this article can be found, in the online version, at http://

\section{References}

[1] X.C. Su and J.L. Chen, Site-specific tagging of proteins with paramagnetic ions for determination of protein structures in solution and in cells, Acc. Chem. Res. 52 (2019) 1675-1686.

[2] (a) P. Ghezzi, V. Bonetto, M. Fratelli, Thiol-disulfide balance: from the concept of oxidative stress to that of redox regulation, Antioxid. Redox Signal. 7 (2005) 964-972. (b) M. Fratelli, H. Demol, M. Puype, S. Casagrande, I. Eberini, M. Salmona, V. Bonetto, M. Mengozzi, F. Duffieux, E. Miclet, A. Bachi, J. Vandekerckhove, E. Gianazza, P. Ghezzi, Identification by redox proteomics of glutathionylated proteins in oxidatively stressed human $\mathrm{T}$ lymphocytes, Proc. Natl. Acad. Sci. U. S. A. 99 (2002) 3505-3510. (c) C. Jacob, G.I. Giles, N.M. Giles, Helmut Sies, Sulfur and selenium: The role of oxidation state in protein structure and function, Angew. Chem. Int. Ed. 42 (2003) 4742-4758.

[3] (a) M.T. Forrester, J.S. Stamler, A classification scheme for redox-based modifications of 
proteins, Am. J. Respir. Cell Mol. Biol. 36 (2007) 135-137. (b) D.P. Jones, Y.M. Go, Mapping the cysteine proteome: analysis of redox-sensing thiols, Curr. Opin. Chem. Biol. 15 (2011) 103-112. (c) C. Jacob, G.I. Giles, N.M. Giles, H. Sies, Sulfur and selenium: The role of oxidation state in protein structure and function, Angew. Chem. Int. Ed. 42 (2003) $4742-4758$.

[4] (a) P.A. Schwartz, P. Kuzmic, J. Solowiej, S. Bergqvist, B. Bolanos, C. Almaden, A. Nagata, K. Ryan, J. Feng, D. Dalvie, J.C. Kath, M. Xu, R. Wani, and B.W. Murray, Covalent EGFR inhibitor analysis reveals importance of reversible interactions to potency and mechanisms of drug resistance, Proc. Natl. Acad. Sci. U. S. A. 111 (2014) 173-178. (b) C.E. Paulsen, T.H. Truong, F.J. Garcia, A. Homann, V. Gupta, S.E. Leonard, K.S. Carroll, Peroxide-dependent sulfenylation of the EGFR catalytic site enhances kinase activity, Nat. Chem. Biol. 8 (2011) 57-64. (c) R. Wani, N.S. Bharathi, J. Field, A.W. Tsang, C.M. Furdui, Oxidation of Akt 2 kinase promotes cell migration and regulates G1-S transition in the cell cycle, Cell Cycle 10 (2011) 3263-3268.

[5] Z. Klochona, D. Petrasona, P. Joppa, Z. Dorkova, R. Tkacova, The association between oxidative stress and obstructive lung impairment in patients with COPD, Physiol. Res. 56 (2007) 51-56.

[6] (a) K.P. Kepp, Bioinorganic chemistry of Alzheimer's disease, Chem. Rev. 112 (2012) 5193-5239. (b) A.J. Abrams, A. Farooq, G.F. Wang, S-nitrosylation of apoE in Alzheimer's disease, Biochemistry 50 (2011) 3405-3407.

[7] E.A. Sabens, A.M. Distler, J.J. Mieyal, Levodopa deactivates enzymes that regulate thiol-disulfide homeostasis and promotes neuronal cell death: implications for therapy of Parkinson's disease, Biochemistry 49 (2010) 2715-2724.

[8] (a) M. Kalousova, J. Skrha, T. Zima, Advanced glycation end-products and advanced oxidation protein products in patients with diabetes mellitus, Physiol. Res. 51 (2002) 597-604. (b) E. Dursun, M. Timur, B. Dursun, G. Süleymanlar, T. Ozben, Protein oxidation in type 2 diabetic patients on hemodialysis, J. Diabetes. Complicat. 19 (2005) 142-146.

[9] K.G. Reddie, K.S. Carroll, Expanding the functional diversity of proteins through cysteine oxidation, Curr. Opin. Chem. Biol. 12 (2008) 746-754.

[10] T.D. Nolin, M.E. McMenamin and J. Himmelfarb, Simultaneous determination of total homocysteine, cysteine, cysteinylglycine, and glutathione in human plasma by high-performance liquid chromatography: Application to studies of oxidative stress, J. Chromatogr., B 852 (2007) 554-561.

[11] Y. Ogasawara, Y. Mukaib, T. Togawa, T. Suzuki, S. Tanabe, K. Ishii, Determination of plasma thiol bound to albumin using affinity chromatography and high-performance liquid chromatography with fluorescence detection: Ratio of cysteinyl albumin as a possible biomarker of oxidative stress, J. Chromatogr., B 845 (2007) 157-163.

[12] G. Chen, L. Zhang, J. Wang, Miniaturized capillary electrophoresis system with a carbon 
nanotube microelectrode for rapid separation and detection of thiols, Talanta 64 (2004) 1018-1023.

[13] T. Inoue, J.R. Kirchhoff, Determination of thiols by capillary electrophoresis with amperometric detection at a coenzyme pyrroloquinoline quinone modified electrode, Anal. Chem. 74 (2002) 1349-1354.

[14] X.C. Su, J.L. Chen, Site-Specific Tagging of Proteins with Paramagnetic Ions for determination of protein structures in solution and in cells, Acc. Chem. Res. 52 (2019) $1675-1686$.

[15] A.S. Klymchenko, Solvatochromic and fluorogenic dyes as environment-sensitive probes: Design and biological applications, Acc. Chem. Res. 50 (2017) 366-375.

[16] (a) Y.Y. Wang, X.F. Yang, Y.G. Zhong, X.Y. Gong, Z. Li, H. Li, Development of a red fluorescent light-up probe for highly selective and sensitive detection of vicinal dithiol-containing proteins in living cells, Chem. Sci. 7 (2016) 518-524. (b) Y.Y. Wang, Y.G. Zhong, Q. Wang, X.F. Yang, Z. Li, H. Li, Ratiometric fluorescent probe for vicinal dithiol-containing proteins in living cells designed via modulating the intramolecular charge transfer-twisted intramolecular charge transfer conversion process, Anal. Chem. 88 (2016) 10237-10244. (c) F. Liu, H.J. Liu, X.J. Liu, W. Chen, F.L. Wang, R.Q. Yu, J.H. Jiang, Mitochondrion-targeting, environment-sensitive red fluorescent probe for highly sensitive detection and imaging of vicinal dithiol-containing proteins, Anal. Chem. 89 (2017) 11203-11207.

[17] (a) K. Imai, T. Toyo'oka, Y. Watanabe, A novel fluorogenic reagent for thiols: ammonium 7-fluorobenzo-2-oxa-1, 3-diazole-4-sulfonate, Anal. Biochem. 128 (1983) 471-473. (b) T. Toyo'oka, K. Imai, New fluorogenic reagent having halogenobenzofurazan structure for thiols: 4-(aminosulfonyl)-7-fluoro-2， 1， 3-benzoxadiazole, Anal. Chem. 56 (1984), 2461-2464.

[18] (a) T.O. Sippel, New fluorochromes for thiols: Maleimide and iodoacetamide derivatives of a 3-phenylcoumarin fluorophore. J. Histochem. Cytochem. 29 (1981) 314-316. (b) T.O. Sippel, Microfluorometric analysis of protein thiol groups with a coumarinylphenylmaleimide, J. Histochem. Cytochem. 29 (1981) 1377-1381. (c) G.D. Hu, B.X. Zhang, P.C. Zhou, Y.N. Hou, H.Y Jia, Y.X. Liu, L. Gan, H. Zhang, Y.H. Mao and J.G. Fang, Depletion of protein thiols and the accumulation of oxidized thioredoxin in parkinsonism disclosed by a red-emitting and environment-sensitive probe, J. Mater. Chem. B 7 (2019) 2696-2702.

[19] (a) W. Lin, L. Yuan, Z. Cao, Y. Feng, L. Long, A sensitive and selective fluorescent thiol probe in water based on the conjugate 1,4-addition of thiols to alpha, beta-unsaturated ketones, Chemistry 15 (2009) 5096-5103. (b) L. Yi, H. Li, L. Sun, L. Liu, C. Zhang, Z. Xi, A highly sensitive fluorescence probe for fast thiol-quantification assay of glutathione reductase, Angew. Chem. Int. Ed. 48 (2009) 4034-4037. (c) F. J. Huo, Y. Q. Sun, J. Su, J. B. Chao, H. J. Zhi, C. X. Yin, Colorimetric detection of thiols using a chromene molecule, Org. 
Lett. 11 (2009) 4918-4921. (d) S. Cai, N.N. Shao, Y.Y. Chen, A.B. Li, J. Pan, H.J. Zhu, H.B. Zou, S. Zeng, L.L. Sun, J.H. Zhao, Enantioselective reduction of $\alpha, \beta$-unsaturated ketones and aryl ketones by perakine reductase, Org. Lett. 21 (2019) 4411-4414. (e) J.H. Yum, S. Park, R. Hiraga, I. Okamura, S. Notsu, H. Sugiyama, Modular DNA-based hybrid catalysts as a toolbox for enantioselective hydration of $\alpha, \beta$-unsaturated ketones, Org. Biomol. Chem. 17 (2019) 2548-2553.

[20] (a) X.L. Jin, S.P. Wu, M.Y. She, Y.F. Jia, L.K. Hao, B. Yin, L.Y. Wang, M. Obst, Y.H. Shen, Y.M. Zhang, J.L. Li, A novel fluorescein-based fluorescent probe for detecting $\mathrm{H}_{2} \mathrm{~S}$ and its real applications in blood plasma and biological imaging, Anal. Chem. 88 (2016) 11253-11260. (b) Y.Y. Ning, J.H. Cui, Y.W. Lu, X.Q. Wang, C.N. Xiao, S.P. Wu, De novo design and synthesis a novel colorimetric fluorescent probe based on naphthalenone scaffold for the selective detection of hypochlorite and its application in living cells, Sens. Actuators, B 269 (2018) 322-330. (c) J.L. Du, X.L. Li, S.S. Ruan, Y.C. Li, F. Ren, Y.J. Cao, X.Q. Wang, Y.M. Zhang, S.P. Wu, J.L. Li. Rational design of a novel turn-on fluorescent probe for detecting hydrazine with barbituric acid as recognition group and bioimaging, Analyst (2020) DOI: 10.1039/C9AN02058F. (d) L.L. Yang, S. S. Ruan, A.Q. Zhang, M.Y. Hu, J. Zhang, K.J. Sheng, J. Tian, Y.M. Zhang, S.P. Wu, J.L. Li. A colorimetric and ratiometric fluorescent probe with meldrum's acid as the recognition group for in vitro and in vivo imaging of hypochlorite, Dyes Pigm. 175 (2020) 108144.

[21] (a) H.Y. Bai, J.H. Qian, H.Y. Tian, W.W. Pan, L.Y. Zhang, W.B. Zhang, Fluorescent polarity probes for identifying bovine serum albumin: Amplification effect of para-substituted benzene, Dyes Pigm. 103 (2014) 1-8. (b) Q. Sun, J.H. Qian, H.Y. Tian, L.P. Duan, W.B. Zhang, Rational design of biotinylated probes: Fluorescent turn-on detection of (strept) avidin and bioimaging in cancer cells, Chem. Comm. 50 (2014) 8518-8521. (c) Q. Sun, H.Y. Tian, H.R. Qu, D.S. Sun, Z. Chen, L.P. Duan, W.B. Zhang, J.H. Qian, Discrimination between streptavidin and avidin with fluorescent affinity-based probes, Analyst 140 (2015) 4648-4653.

[22] (a) X. Chen, H. Wu, C.M. Park, T.H. Poole, G. Keceli, N. O. Devarie-Baez, A.W. Tsang, W.T. Lowther, L.B. Poole, S.B. King, M. Xian, C.M. Furdui, Discovery of heteroaromatic sulfones as a new class of biologically compatible thiol-selective reagents. ACS Chem. Biol. 12 (2017) 2201-2208. (b) D. Zhang, I. Macinkovic, N.O. Devarie-Baez, J. Pan, C.M. Park, K.S. Carroll, M.R. Filipovic, M. Xian, Detection of protein s-sulfhydration by a tag-switch technique, Angew. Chem. Int. Ed. 53 (2014) 575-581.

[23] X. Pan, Z. Liang, J. Li, S. Wang, F. Kong, K. Xu, B. Tang, Active-site-matched fluorescent probes for rapid and direct detection of vicinal-sulfydryl-containing peptides/proteins in living cells, Chem.-Eur. J. 21 (2015) 2117-2122.

[24] G.S. Loving, M. Sainlos, B. Imperiali, Monitoring protein interactions and dynamics with solvatochromic fluorophores, Trends Biotechnol. 28 (2010) 73-83 
[25] (a) Q. Jin, L. Feng, S.J. Zhang, D.D. Wang, F.J. Wang, Y. Zhang, J.N. Cui, W.Z. Guo, G.B. Ge, L. Yang, Real-Time Tracking the Synthesis and Degradation of Albumin in Complex Biological Systems with a near-Infrared Fluorescent Probe, Anal Chem. 89 (2017) 9884-98911. (b) G.B. Ge, L. Feng, Q. Jin, Y.R. Wang, Z.M. Liu, X.Y. Zhu, P. Wang, J. Hou, J.N. Cui, L. Yang, A novel substrate-inspired fluorescent probe to monitor native albumin in human plasma and living cells, Anal Chim Acta. 989 (2017) 71-79. 